\title{
Pengembangan Bahasa Anak Melalui Pembelajaran Iqro' Usia 5-6 Tahun di TK Islam Akramunnas Pekanbaru
}

\author{
Radhiyatul Fithri' ${ }^{1)}$, Baidarus ${ }^{2)}$, Rindi Sri Rezeki ${ }^{3)}$ \\ ${ }^{1)}$ Sekolah Tinggi Keguruan dan Ilmu Pendidikan Aisyiyah \\ email: fithrighazal_78@yahoo.com \\ ${ }^{2)}$ Universitas Muhammadiyah Riau \\ email: bayu@umri.ac.id
}

\begin{abstract}
Abstrak
Pengembangan bahasa memungkinkan anak belajar memahami dan mengontrol diri sendiri. Salah satu cara dengan menerapkan metode pembelajaran iqro" sehingga anak menjadi lebih baik dan anak lebih aktif hal ini disebabkan anak lebih mudah memahami, anak melakukan dengan senang dan sesuai dengan minat atau keinginan anak tanpa ada sesuatu paksaan. Tujuan dalam penelitian ini adalah untuk mengetahui pengembangan bahasa anak melului pembelajaran iqro"e usia 5-6 tahun di TK Islam Akramunas Pekanbaru. Penelitian ini berjenis kualitatif dengan pendekatan deslriptif Penelitian ini dilaksanakan di TK Islam Akramunas Pekanbaru. Subjek yang akan diteliti adalah guru dan anak. Guru terdiri atas 2 orang dan anak terdiri atas 19 orang anak. Berdasarkan hasil observasi mengenai pengembangan bahasa anak dalam pembelajaran iqro"e usia 5 sampai 6 tahun di TK Islam Akramunnas Pekanbaru dimana 102 tanggapan atau 53,7\% hasil observasi dengan jawaban "Ya" sementara 88 tanggapan atau 46,3\% hasil observasi dengan jawaban "Tidak". Sementara penyajian dengan menggunakan rumus dimana nilai yang dihasilkan sebesar 0,54 atau $54 \%$ berada dalam kriteria penilaian cukup baik mengenai pengembangan bahasa anak dalam pembelajaran iqro ${ }^{c e}$ usia 5 sampai 6 tahun di TK Islam Akramunnas Pekanbaru. Dari hasil observasi yang telah dilaksanakan dimana pembelajaran iqro dapat mengembangkan bahasa anak sebab dengan belajar iqro memungkinkan anak belajar memahami dan mengontrol diri sendiri dan secara tidak disengaja mereka mengembangkan pengetahuan tentang sistem fonologi, sintaksis, semantik dan sistem pragmatic.
\end{abstract}

Kata Kunci : Pengembangan Bahasa Dan Pembelajaran Iqro’ 


\section{PENDAHULUAN}

Perkembangan adalah suatu proses perubahan dimana anak belajar menguasai tingkat yang lebih tinggi dari berbagai aspek. Salah satu aspek penting dalam perkembangan adalah aspek perkembangan bahasa. Pengembangan bahasa memungkinkan anak belajar memahami dan mengontrol diri sendiri. Ketika anak belajar berbicara, secara tidak disengaja mereka mengembangkan pengetahuan tentang sistem fonologi, sintaksis, semantik dan sistem pragmatic. Pengetahuan tersebut Beverly Otto (2015:79) menyebutnya sebagai elemen bahasa. Pengetahuan ini, dapat dikembangkan oleh anak dalam kehidupan dilingkungannya, baik di rumah, dalam kehidupan bermain, dan si sekolah. Dalam kehidupan di sekolah, pengetahuan guru tentang bahasa anak berguna untuk kepentingan perencanaan, pelaksanaan, dan dalam evaluasi pembelajaran. Dengan demikian guru hendaklah memiliki pengetahuan yang luas tentang perkembangan bahasa anak dan cara mengembangkannya, agar kelak mereka memiliki keterampilan berbahasa yang benar dan baik, baik dalam mendengarkan, berbicara, membaca, maupun menulis. Perkembangan bahasa untuk anak usia dini meliputi empat pengembangan yaitu mendengarkan, berbicara, membaca dan menulis. Pengembangan tersebut harus dilakukan seimbang agar memperoleh pengembangan membaca dan

menulis yang optimal.

Perkembangan bahasa untuk anak taman kanak-kanak berdasarkan acuan standar pendidikan anak usia dini No. 58 tahun 2009, mengembangkan tiga aspek yaitu menerima bahasa, mengungkapkan bahasa, dan keaksaraan. Ahmad Susanto (2011 : 35) menjelaskan bahwa kemampuan bahasa anak khususnya pada kategori reseptif dan ekspresif juga berkembang cepat yaitu menerima bahasa, pada tingkat pencapaian perkembangan yakni menyimak perkataan orang lain dan memahami cerita yang dibacakan yang mengacu pada RKH.

Dalam pengembangan bahasa salah satunya yang dikembangkan pada anak usia dini adalah dengan pembelajaran iqro'. Seperti yang kita ketahui pada saat ini pembelajaran iqro ${ }^{\text {ee }}$ merupakan salah satu pembelajaran yang sangat penting bagi anak usia dini terutama pada taman kanak-kanak yang berbasis atau bernuansa Islam. Dengan belajar iqro' anak bisa lebih mengenal huruf hijaiyah di dalam iqro, anak dapat menghafal atau mengingat huruf huruf hijaiyah yang bisa ditangkap di otaknya, juga mempermudah anak dapat membaca al-qurean serta menghapal ayat - ayat al-qur"an. Pengucapan setiap huruf-huruf hijaiyah, kata serta rangkaian kata menjadi bentuk kalimat yang dibaca pada iqro' merupakan sebuah proses pengembangan bahasa anak. Sebab dalam pembelajaran iqro' tersebut akan terkait dengan membaca, menulis, menyimak dan mengucapkan.

Berdasarkan data observasi awal di TK Islam Akramunas Pekanbaru bahwa dari 11 anak terdapat 4 orang anak yang belum sepenuhnya menyimak, mengulangi dan 
mempelajari huruf-huruf hijaiyah yang disampaikan oleh guru. Hal ini terbukti adanya sebagian anak yang dalam pengucapan huruf ب belum sempurna, misalnya ketika guru menyebutkan huruf ب ب ن anak tidak bisa mengikuti kembali apa yang di ucapkan oleh guru. Berdasarkan hasil observasi fenomena yang terjadi dalam pengembangan bahasa anak melalui pembelajaran iqro' masih belum sempurna karena anak masih sulit dalam melafazkan huruf-huruf hijaiyah, bahkan juga membaca iqro tersebut. Hal ini mungkin juga disebabkan metode dan media pembelajaran iqro' yang digunakan guru kurang variatif. Berdasarkan latar belakang diatas, maka peneliti termotivasi melakukan penelitian dengan judul "Analisis Pengembangan Bahasa Anak melalui Pembelajaran Iqro' Usia 5-6 Tahun di TK Islam Akramunas Pekanbaru". Menurut Dini (1996: 78) bahasa adalah suatu sistem simbol yang digunakan untuk berkomunikasi dengan orang lain. Pada manusia bahasa ditandai oleh daya cipta yang tidak akan pernah habis dan adanya system aturan yang meliputi fonologi (uni suara), sintaksis (tata bahasa), semantic (variasi arti), dan pragmatic (penggunaan bahasa). Melalui bahasa anak dapat menceritakan pengalaman dan perasaannya melalui simbol-simbol yang dapat dipahami oleh orang lain. Hal tersebut sejalan dengan pendapat para ahli yang mengatakan bahwa bahasa merupakan suatu sistem lambang yang digunakan sebagai alat komunikasi oleh masyarakat yang bersifat arbitrer dan manusiawi, dengan menggunakan bahasa untuk berkomunikasi, anak akan mendapatkan banyak sekali kosa kata sekaligus dapat mengekspresikan perasaannya dan anak dapat belajar untuk melibatkan diri dalam sebuah percakapan.

Bahasa berfungsi sebagai alat komunikasi, alat untuk mengembangkan ekspersi, dan alat untuk mengembangkan kemampuan intelektual serta kemampuan dasar anak. Lima fungsi bahasa menurut Bromley dalam Dini (1996:82 ) adalah sebagai berikut: (a) Bahasa menjelaskan keinginan dan kebutuhan individu. (b) Bahasa dapat merubah dan mengontrol perilaku. (c) Bahasa membantu perkembangan kognitif. (d) Bahasa membantu mempererat interaksi dengan ornag lain. (e) Bahasa mengekspersikan keunikan individu.

Perkembangan bahasa anak dipengaruhi oleh beberapa faktor, diantaranya faktor kesehatan, intelegensi, status sosial ekonomi keluarga, jenis kelamin, dan hubungan keluarga (Agus F Tanyong:2007:121). Moeslichatoen (2004: 45) juga mengemukakan bahwa "ada dua alasan yang menyebabkan perkembangan bahasa berkaitan dengan perkembangan kognitif. Pertama, anak harus menggunakan bahasa untuk berkomunikasi atau berbicara dengan orang lain. Kemampuan ini disebut dengan kemampuan bahasa secara eksternal dan menjadi dasar bagi kemampuan berkomunikasi kepada diri sendiri. Kedua, transisi dari kemampuan berkomunikasi secara eksteranal kepada kemampuan 
berkomunikasi secara interanal membutuhkan waktu yang cukup panjang. Transisi ini terjadi pada fase praoperasional, yaitu pada usia 2-7 tahun. Selama masa ini, berbicara pada diri sendiri merupakan bagian dari kehidupan anak. Ia akan berbicara dengan berbagai topik dan tentang berbagai hal, melompat dari satu topik ke topik lainya. Pada saat ini anak sangat senang bermain bahasa dan beranyanyi. Pada usia 5-6 tahun, anak sudah dapat berbicara dengan bahasa yang baik, hanya sedikit kesalahan ucapan yang di lakukan anak pada masa ini. Ketiga, pada perkembangan selanjutnya anak akan bertindak tanpa berbicara. Apabila hal ini terjadi, maka anak telah mampu menginteranalisasi percakapan egosentris (berdasarkan sudut pandang sendiri) ke dalam percakapan di dalam dri sendiri.

Pembelajaran iqro merupakan pembelajaran awal sebelum membaca al quran. Sebelum belajar iqro akan diawali dengan pengajaran huruf hijaiyah terlebih dahulu kemudian dilanjutkan dengan pembelajaran iqro'jilid satu dalam bentuk pengajaran huruf hijaiyah yang bersyakal. Selanjutnya pada iqro' jilid berikutnya dalam bentuk pembelajaran kata dan kalimat-kalimat pendek dan panjang hingga akhirnya anak akan mampu untuk membaca al quran dengan baik dan benar. Pada pembelajaran iqro' anak akan diajarkan dengan metode membaca (qira-ah) dengan beberapa tahap sebagai berikut: (a) Metode harfiyah, yaitu guru memulai pelajaran dengan mengajarkan huruf hijaiyah satu per satu. Sedangkan siswa disini membacanya dengan lambat karena cenderung membacanya huruf per huruf, (b) Metode shauthiyah, yaitu pengajaran yang dinulai dari huruf, kemudian suku kata, lalu kata (c) Metode suku kata, yaitu siswa terlebih dahulu belajar suku kata, kemudian merangkai suku kata tersebut menjadi kata (d) Metode kata, yaitu belajar dari kata, kemudian belajar huruf-huruf yang membentuk kata tersebut. (e) Metode kalimat, yaitu guru menampilkan sebuah kalimat pendek dikartu atau papan tulis, kemudian membacanya beberapa kali, dan siswa menirukan. Lalu menambahkan satu kata baru, kemudian membacanya yang diikuti oelh siswa. Guru membandingkan dua kalimat tersebut sehingga diketahui perbedaan dan persamaannya (f) Metode gabungan, yaitu meramu semua metode dengan memperhatikan sisi baiknya, dan tidak terpaku pada metode tertentu. Dengan beberapa rangkaian metode dan langkah tersebut akan menghartarkan ank/siswa untuk dapat membaca al quran dengan baik dan benar. (HM. Budianto:1990:12)

Menurut Bambang Yulianto ( 2000: 25) Metode Mengajar Iqro' dapat dilakukan dengan tiga metode yaitu (1) metode individual atau sorongan yaitu mengajar dengan cara satu persatu (secara individu) sesuai dengan materi pelajaran yang dipelajari atau dikuasai murid. Pada waktu menunggu giliran belajar secara individu, maka murid yang lain diberi tugas menulis/membaca atau yang lainnya, (2) metode Sorongan adalah sebuah sistem belajar dimana 
para murid maju satu persatu untuk membaca dan menguraikan isi kitab di hadapan seorang guru atau kiyai. Maksudnya adalah metode sorongan merupakan metode individual dimana murid mendatangi guru untuk mengkaji suatu kitab dan guru membimbingnya secara langsung, (3) metode Klasikal atau bandongan adalah mengajar dengan memberikan materi pelajaran secara missal (bersama-sama) kepada sejumlah murid dalam sat kelompok/kelas. Metode bandongan adalah salah satu metode pembelajaran dalam pendidikan Islam. Dimana murid tidak menghadap guru satu persatu, tapi semua murid didik menghadap guru dengan membaca iqro ${ }^{c e}$ masing-masing. Kemudian guru membacakan ,menerangkan kalimat demi kalimat dari buku iqro yang dipelajari, sementara murid secara.

Faktor-Faktor

Mempengaruhi Pembelajaran Iqro' menurut As'ad Humam (1990:25) adalah (1) lingkungan keluarga. Keluarga merupakan kelompok social pertama dalam kehidupan social anak, diantara factor yang terkait dengan keluarga adalah : social ekonomi, keluarga, keutuhan keluarga, serta sikap dan kebiasaan orang tua (2) faktor luar rumah. Pengalaman awal membaca iqro diluar rumah melengkapi pengalaman didalam rumah dan merupakan penentu yang penting bagi sikap anak dalam keagamaan.

\section{METODE}

Penelitian ini menggunakan pendekatan kualitatif dan jenis penelitiannya adalah deskriptif. Penelitian deskriptif kualitatif merupakan salah satu dari jenis penelitian yang termasuk dalam jenis penelitian kualitatif. Ada pun tujuan dari penelitian ini adalah untuk mengungkapkan kejadian atau fakta, keadaan, fenomena, variable dan keadaan yang terjadi saat penelitian berlangsung dengan menyuguhkan apa yang sebenarnya terjadi. Metode deskriptif adalah suatu metode yang yang digunakan untuk menggambarkan atau menganalisis suatu hasil penelitian tetapi tidak digunakan membuat kesimpulan yang lebih luas (Sugiyono, 2005). Waktu dalam penelitian ini terhitung sejak bulan Januari hingga Desember 2018. Adapun tempat penelitian ini adalah TK Islam Akramunas Pekanbaru. Subjek yang akan diteliti adalah guru dan anak. Guru terdiri atas 2 orang dan anak terdiri atas 19 orang anak perempuan dan 5 orang anak laki-laki yang ada dikelas B4. Sedangkan objek yang akan diteliti adalah pengembangan bahasa anak usia 5-6 tahun pada kanak-kanak TK Islam Akramunas Pekanbaru. Teknik pengumpulan data adalah teknik observasi, wawancara dan dokumentasi. Teknik obseravasi untuk melakukan pengamatan terhadap objek objek yang dapat dijadikan sebagai sumber masalah sementara wawancara dilakukan untuk menggali data berdasarkan komunikasi kepada informan (guru) pada objek penelitian dan teknik Dokumentasi digunakan untuk memperoleh data tentang anak, sekolah dan foto-foto tentang wawancara dengan guru TK Islam 
Akramunas Pekanbaru. Adapun teknik analisa data peneliti akan melaksanakan analisis dengan langkah - langkah sebagai berikut: (1). Mencatat hasil penelitian yang diperoleh baik melalui observasi, dokumentasi maupun dalam bentuk transkip, (2) setelah semua data terkumpul lalu data dipilah-pilah untuk menjalankan serta mengarahkan dan membuang yang tidak penting, (3) mengklarifikasikan data - data tersebut dengan focus penelitian (4) menganalisis data - data tersebut dan memberikan interpensi terhadap data yang diperoleh dengan cara memberikan penjelasan yang bersifat kualitatif, (5) penarikan kesimpulan agar maksud dari penelitian ini dapat memberi arti.

\section{HASIL DAN PEMBAHASAN}

Berdasarkan hasil observasi mengenai pengembangan bahasa anak dalam pembelajaran iqro ${ }^{\text {ee }}$ usia 5 sampai 6 tahun di TK Islam Akramunnas Pekanbaru dimana 102 tanggapan atau $53,7 \%$ hasil observasi dengan jawaban "Ya". Sementara 88 tanggapaan atau 46,3\% hasil observasi dengan jawaban "Tidak". Berikut adalah hasil penyajian dengan menggunakan rumus dimana nilai yang dihasilkan sebesar 0,54 atau 54\% berada dalam kriteria penilaian cukup baik mengenai pengembangan bahasa anak dalam pembelajaran iqro ${ }^{\text {ee }}$ usia 5 sampai 6 tahun di TK Islam Akramunnas Pekanbaru. Dari hasil observasi yang telah dilaksanakan dimana pengembangan bahasa memungkinkan anak belajar memahami dan mengontrol diri sendiri. Ketika anak belajar berbicara, secara tidak disengaja mereka mengembangkan pengetahuan tentang sistem fonologi, sintaksis, semantik dan sistem pragmatic. Pembelajaran berupaya mengubah masukan berupa anak yang belum terdidik, menjadi anak yang terdidik, anak yang belum memiliki pengetahuan tentang sesuatu, menjadi anak yang memiliki pengetahuan. Sebagaimana dikemukakan sebelumnya bahwa metode pengembangan bahasa anak mempunyai beberapa macam kelebihan. Dari wawancara yang telah dilaksanakan pembelajaran iqro" ${ }^{\text {ee }}$ sudah dilakukan sejak anak pertama kali masuk ke sekolah serta terdapat beberapa anak yang sudah mendapat pembelajaran iqro ${ }^{\text {ee }}$ pada saat dirumah. Hal ini adalah satu bentuk pembelajaran yang dilakukan kepada anak didalam mengenal huruf-huruf hijaiyah yang bertujuan untuk memberikan kemudahan kepada anak didalam membaca al-qurean. Pentingnya pembelajaran iqro"e pada usia dini diharapkan dapat memberikan peningkatan pengetahuan anak, terutama pembelajaran mengenai pengenalan huruf-huruf hijaiyah yang ada didalam iqro" sehingga hal ini akan memberikan kemudahan bagi anak untuk membaca ayat-ayat yang ada didalam al-qurean. Maka peran orang tua dan guru sangat penting untuk menerapkan metode pembelajaran dengan iqro" ${ }^{\text {ee }}$ sehingga dengan metode ini diharapkan dapat memberikan dan menambah pengetahuan anak didalam mengenal hurufhuruf hijaiyah dengan baik. Sementara anak dapat menghafal atau mengingat huruf - huruf hijaiyah 
yang bisa ditangkap di otaknya dengan memberikan kemudahan kepada anak untuk menghafal atau mengingat huruf-huruf hijaiyah dimana selain

menerapkan pembelajaran dengan iqro guru juga memberikan beberapa variasi belajar seperti guru membuat sebuah ayat yang kemudian disambung oleh anak serta dengan cara membuat kartukartu huruf hijaiyah dan menerapkan dalam sebuah permainan. Pembelajaran

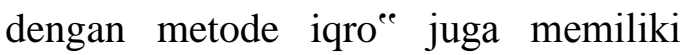
tujuan untuk memberikan kemudahan kepada anak untuk menangkap, menghafal dan mengingat dengan baik huruf-huruf hijaiyah yang ada didalam

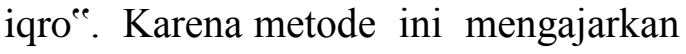
anak untuk selalu membaca dengan berulang-ulang mengenai huruf hijaiyah, sehingga anak dapat mengingat dan menghafal hurufhuruf hijaiyah yang ada didalam iqro"e dengan baik dan benar. Selain itu variasi pembelajaran juga penting dilakukan untuk menarik perhatian anak agar tidak merasa bosan didalam pembelajaran. Selain pembelajaran dengan iqro ${ }^{\text {ee }}$ guru juga menerapkan pembelajaran dengan menyambung ayat yang sudah dituliskan oleh guru kepada anak. Setelah selesai menyambungkan ayat, kemudian guru meminta anak untuk membaca dengan berulang-ulang agar anak dapat dengan mudah untuk menghafal hurufhuruf hijaiyah dengan cepat. Metode pembelajaran dengan iqro ${ }^{\text {ee }}$ adalah salah satu metode yang sangat sederhana didalam mempermudah anak belajar membaca al-qurean dengan cepat, karena pembelajaran dengan iqro" memfokuskan anak untuk terlebih dahulu mempelajari dasar dasar dengan mengenalkan huruf-huruf hijaiyah. Dengan berkambangnya pengetahuan anak

mengenai huruf-huruf maka hal ini dapat memberikan kemudahan anak untuk

membaca al-qurean. Banyak cara yang dapat dilakukan oleh guru untuk memberikan

kemudahan kepada anak didalam menghafal ayat-ayat al-qurean diantara nya seperti guru mengajak anak belajar sambil bermaian serta dengan menerapkan kepada anak untuk mengulang kembali seperti mambaca sebelum memulai pelajaran dan sesudah selesai balajar. Meningkatnya pengetahuan anak mengenai hurufhuruf hijaiyah didalam iqro ${ }^{\text {ee }}$ dapat membantu didalam menghafal ayatayat yang ada didalam al-qur"an. Karena pada dasarnya pembelajaran dengan metode iqro"e adalah salah satu metode yang mengenalkan anak mengenai huruf-huruf hijaiyah sehingga dapat membantu anak untuk menghafal ayat-ayat didalam al-qurean. Berdasarkan kelebihan tersebut, maka penulis yakin terdapat kaitan antara metode pengembangan bahasa dengan membaca iqro. Menurut Mahfudh Shalahudin (1998:29) dalam bukunya metode pendidikan agama mendefinisikan metode adalah cara tertentu yang paling tepat digunakan untuk menyampaikan suatu bahan pelajaran sehingga tujuan dapat dicapai. Sedangkan menurut Winamo, (1994:95) mendefinisikan metode 
adalah cara, dan dalam fungsinya merupakan alat untuk mencapai suatu tujuan, makin baik metode makin baik pula pencapaian tujuan.

\section{KESIMPULAN}

Berdasarkan hasil penelitian yang telah dilaksanakan maka dapat ditarik kesimpulan sebagai berikut :

1. Berdasarkan hasil penelitian dimana pengembangan bahasa anak dalam pembelajaran iqro pada anak usia 5 sampai dengan 6 tahun di TK Islam Akramunnas Pekanbaru sudah cukup baik. Dengan adanya pengembangan bahasa anak menggunakan metode pembelajaran iqo diharapkan dapat meningkatkan pengetahuan dan pemahaman anak mengenai huruf-huruf yang ada didalam al-quran.

2. Menurut guru yang mengajar di TK Islam Akramunnas dimana banyak cara yang dapat digunakan untuk meningkatkan pengetahuan dan pemahaman anak mengenai huruf-huruf yang ada didalam alquran diantaranya seperti guru meminta anak untuk menulis ulang dan membacakannya kembali didepan kelas.

Adapun saran-saran yang dapat penulis berikan berdasarkan hasil penelitian yang telah dilaksanakan adalah sebagai berikut :

1. Untuk kepala sekolah harus ikut serta dalam melakukan evaluasi membaca al-qur"an dengan metode iqro" baik per bulan, per semester ataupun pertahunnya agar pelaksanaan membaca al-qurean dengan metode

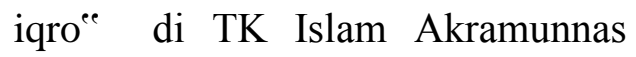
Pekanbaru. dapat meningkat.

2. Kepada guru diharapkan lebih meningkatkan kualitas mengajar membaca al-qur"an dengan metode iqro $^{\text {"e }}$ dengan mengajarkan secara komunikatif, guru hanya mencontohkan awal halawan/pokok pelajaran saja, melakukan pengulangan hanya pada bacaan yang salah saja, memberikan buku/kartu pembatas bacaan iqro kepada orang tua, guru harus memberitahu perkembangan membaca al-qur ${ }^{\text {ee an }}$ dengan metode

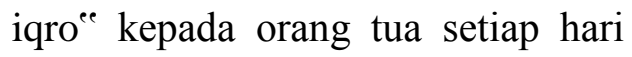
walaupun hanya lewat lisan saja dan guru juga harus melakukan diskusi dengan orang tua dalam hal-hal yang akan dicapai anak dalam

3. membaca al-qur an dengan metode iqro" setiap semester, membahas keinginan orang tua dalam peningkatan membaca al-qurean setiap semester ataupun membahas kekurangan yang harus diperbaiki siswa serta hal-hal yang harus ditingkatkan dalam membaca alqur"ean dengan metode iqro"e baik dilakukan per minggu, per bulan ataupun per semester.

\section{DAFTAR PUSTAKA}

[1] Agus F. Tanyong. 2009. Pengembangan Anak Usia Dini. Jakarta. PT. Gramedia Widiasarana Indonesia 
[2] Ahmad Susanto. 2011.

Perkembangan Anak Usia Dini.

Pengantar Dalam Berbagai

Aspeknya. Jakarta : Kencana

[3] As'ad Humam, 1990, Cara cepat belajar Membaca Al Quran, Yogyakarta, Team tadarus AMM,

[4] Bambang Yulianto, 2000, Pedoman Mudah Membaca Al Quran Metode A Ba Ta Tsa, Jakarta: A Ba Ta Tsa group

[5] Beverly Otto. 2015. Pergembangan Bahasa Pada Anak Usia Dini. Jakarta. Prenadamedia Group.

[6] Dini Daeng. 1996. Metode Mengajar Di Taman Kanak - Kanak, Bagian 2. Jakarta : Depdiknas

[7] HM Budianto, 1990, Prinsip-prinsip Metodologi Buku Iqra', Yogyakarta, team tadarus "AMM"

[8] Moeslichatoen. 2004. Metode Pengajaran Di Taman Kanak Kanak. Jakarta : Sugiyono.2012. Memahami Penelitian Kualitatif. Bandung : CV . Alfabeta 